\title{
In vivo toxicity of a new antifungal agent 2,4-dithiophenoxy-1-iodo-4-bromo benzene: a follow up on our in vitro study
}

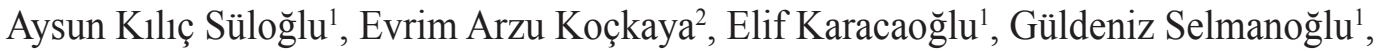 \\ and Elif Loğoğlu ${ }^{3}$
}

Hacettepe University, Faculty of Science, Department of Biology, Beytepe ${ }^{l}$, The Higher Vocational School of Health Services, Gazi University, Gölbaşı Campus², Gazi University, Faculty of Arts and Sciences, Department of Chemistry, Technical Schools ${ }^{3}$, Ankara, Turkey

[Received in April 2014; CrossChecked in April 2014; Accepted in February 2015]

Triazole fungicide fluconazole has become the most widely used antifungal agent in the world, mainly because of its ability to penetrate well into body fluids and tissues. However, it has been reported to interact with many drugs and because of its common use, the risk of resistance to fluconazole increases. This calls for new anti-fungal drugs that would be able to replace it. In 2006, a new thialo benzene derivative - 2,4-dithiophenoxy-1-iodo-4-bromo benzene $\left(\mathrm{C}_{18} \mathrm{H}_{12} \mathrm{~S}_{2} \mathrm{IBr}\right)$ - was synthesised with a carbon backbone similar to fluconazole, and, according to the early in vitro tests, much greater efficiency. Followed an in vitro test of its cytotoxicity, in which the new drug showed promising results as an alternative to fluconazole. The aim of this study was take the next step and test $\mathrm{C}_{18} \mathrm{H}_{12} \mathrm{~S}_{2} \mathrm{IBr}$ toxicity in vivo. We opted for a four-week test on Wistar rats, in which the new antifungal agent was orally applied at doses two and a half and five times lower than those of fluconazole. There were no changes in daily food and water consumption, but weight gain in female rats and relative organ weights changed in the treated groups, pointing to sex-related differences in drug metabolism and effects. Fluconazole significantly increased leukocytes and lowered neutrophils whereas $\mathrm{C}_{18} \mathrm{H}_{12} \mathrm{~S}_{2} \mathrm{IBr}$ did not, while other haematological changes in respect to the vehicle control were similar between the treated groups. Differences in cytochrome $\mathrm{c}$ in the liver and kidney suggested greater apoptotic effect of the new drug, but interpretation remains inconclusive, considering that other key indicators (biochemistry and histopathology) do not support greater toxicity. Considering that $\mathrm{C}_{18} \mathrm{H}_{12} \mathrm{~S}_{2} \mathrm{IBr}$ is more active at lower concentrations and has comparable toxic effects to fluconazole in rats, this new compound shows some promise in the treatment of fungal infections. Future, more detailed animal studies are needed, that will include drug interactions and molecular toxicity pathways. If the results are promising, clinical studies should follow.

KEY WORDS: blood biochemistry; cytochrome c; fluconazole; histopathology; in vivo toxicity study

Seventy percent of the people infected by bacteria and fungi develop resistance to one of the antifungal drugs (1). One such drug is the triazole fungicide fluconazole, and the risk of resistance is even greater, as fluconazole is the most widely used among antifungal compounds. This fungicide is designed to inhibit the fungal cytochrome P450 (CYP $\mathrm{P} 450$ ) enzyme but it can also affect the mammalian enzymes.

Apart from the risk of resistance to fluconazole, it has common side effects such as nausea, vomiting, headache, and toxicity issues through interactions with drugs that are metabolised by CYP3A4 (statins and cyclosporine). Therefore, it is still necessary to develop a broad-spectrum antifungal agent with minimal toxicity and risks for human health $(2,3)$.

Correspondence to: Aysun Kılıç Süloğlu, Hacettepe University, Faculty of Science, Department of Biology, 06800 Beytepe, Ankara, Turkey, E-mail: aykilic82@gmail.com
In 2006, Loğoğlu et al. (4) synthesised a new thialo benzene derivative $\mathrm{C}_{18} \mathrm{H}_{12} \mathrm{~S}_{2} \mathrm{IBr}$ with the carbon backbone similar to fluconazole (Figure 1) and tested its biological activity.<smiles>OC(Cn1cncn1)(Cn1cncn1)c1ccc(F)cc1F</smiles><smiles>Brc1cc(Sc2ccccc2)c(I)c(Sc2ccccc2)c1</smiles>

A.

B.

Figure 1 Chemical structure of $\boldsymbol{A}$. Fluconazole, $\boldsymbol{B}$. 2,4-dithiophenoxy-1-iodo-4-bromo benzene $\left(\mathrm{C}_{18} \mathrm{H}_{12} \mathrm{~S}_{2} \mathrm{IBr}\right)$ 
Its minimum inhibition concentration for Candida albicans was four times lower than that of fluconazole. This compound was also more active against Gram-positive (Staphylococcus aureus, Bacillus subtilis) and Gramnegative bacteria (Yersinia enterocolitica, Escherichia coli, Klebsiella pneumoniae).

However, as no toxicity data on this new compound had been known, we tested its toxicity in vitro on L929 mouse fibroblast cell lines (5), using concentrations based on the FDA information for fluconazole (6), only to find that at $250 \mu \mathrm{g} \mathrm{mL}^{-1} \mathrm{C}_{18} \mathrm{H}_{12} \mathrm{~S}_{2} \mathrm{IBr}$ was not cytotoxic and did not induce metabolic changes.

The next logical step was to investigate the in vivo toxicity of the newly synthesised compound as a potential alternative to flucanozole. We therefore designed this study to determine the toxic effects of $\mathrm{C}_{18} \mathrm{H}_{12} \mathrm{~S}$ IBr at subacute doses on the organ systems (7) of Wistar rats and compare them with fluconazole, considering that antifungal azoles have been reported to adversely affect the gastrointestinal, endocrinological, and liver systems (8).

\section{MATERIALS AND METHODS}

\section{Animals and housing}

The study included 50 adult Wistar male and 50 female rats weighing 150-200 g from the Lemali Animal Husbandry, Ankara, Turkey. Throughout the experiments we followed the National Academy of Sciences' Guide for the Care and Use of Laboratory Animals (9). The rats were housed in polycarbonate cages under a 12:12-hour lightand-dark cycle and controlled temperature $\left(22 \pm 2{ }^{\circ} \mathrm{C}\right)$ and humidity $(44 \pm 5 \%)$, with free access to feed and water. Acclimitisation lasted 10 days. Before treatment, the rats were randomised to groups of 20 (10 female and 10 male), but we took care that the groups did not differ in body weight means. All rats were observed for general condition two times a day for the duration of the experiment.

\section{Chemicals and treatment}

2,4-dithiophenoxy-1-iodo-4-bromobenzene $\left(\mathrm{C}_{18} \mathrm{H}_{12} \mathrm{~S}_{2} \mathrm{IBr}\right)$ is one of thiohalo benzene derivatives synthesised by dissolving 1,2,3,5-tetrahalogene benzene in pyridine and adding thiophynole. This compound was prepared from 2,4,6-tribromo and triiodo anilines de novo, as described by Loğoğlu et al. (4).

Fluconazole (Fluzole ${ }^{\circledR}$ tablet, $150 \mathrm{mg}$ ) was purchased from Biofarma (Istanbul, Turkey). Fluconazole and $\mathrm{C}_{18} \mathrm{H}_{12} \mathrm{~S}_{2} \mathrm{IBr}$ were dissolved in ethanol (absolute alcohol: $0.145 \mathrm{mg} \mathrm{kg}^{-1}$ of bw) and administered by oral gavage once a week for four weeks. The control group was receiving no treatment; the vehicle group was receiving $0.145 \mathrm{mg} \mathrm{kg}^{-1}$ bw of ethanol, which served as the vehicle for active compounds, once a week; the fluconazole group was receiving $19.6 \mathrm{mg} \mathrm{kg}^{-1}$ bw of fluconazole a week; the low- dose $\mathrm{C}_{18} \mathrm{H}_{12} \mathrm{~S}_{2} \mathrm{IBr}$ group was receiving $3.92 \mathrm{mg} \mathrm{kg}^{-1}$ bw of $\mathrm{C}_{18} \mathrm{H}_{12} \mathrm{~S}_{2}$ IBr a week; and the high-dose $\mathrm{C}_{18} \mathrm{H}_{12} \mathrm{~S}_{2}$ IBr group $7.84 \mathrm{mg} \mathrm{kg}^{-1}$ bw of $\mathrm{C}_{18} \mathrm{H}_{12} \mathrm{~S}_{2} \mathrm{IBr}$ a week. The fluconazole dose corresponds to the $200 \mathrm{mg}$ dose a $70-\mathrm{kg}$ human receives every day during a 28 -day treatment $(10)$. The tested concentrations of $\mathrm{C}_{18} \mathrm{H}_{12} \mathrm{~S}_{2} \mathrm{IBr}$ were two and a half times and five times lower than that of fluconazole, based on earlier in vitro efficiency findings (4), as no in vivo efficiency has been studied yet.

\section{Histopathology}

The animals were sacrificed by cervical dislocation $24 \mathrm{~h}$ after the final dosing. Liver, kidney, thymus, spleen, and lymph nodes were removed immediately and weighed to calculate relative organ weights (organ:body weight). All tissue samples were fixed in Bouin's solution, embedded in paraffin, cut in 5- $\mu \mathrm{m}$ thick sections and stained with haemotoxylin and eosin for histopathology. The slides were examined under the Olympus BX51 system light microscope (Tokyo, Japan) at 100x and 200x magnification. One hundred kidney glomeruli from 20 animals from each group were selected to measure the minimum (x-axis) and maximum (y-axis) diameter in serial sections using the Bs200pro image analysis program (BAB, Ankara, Turkey). The glomerular volume was calculated as described elsewhere (11).

\section{Immunohistochemistry}

For immunohistochemical tests liver and kidney samples were fixed in $10 \%$ formaldehyde and embedded in paraffin, and 5- $\mu \mathrm{m}$ sections prepared for slides. Slides were stained with rabbit polyclonal primary cytochrome c (cyt-c) antibody and biotinylated secondary goat-anti rabbit IgG (BA-1000, Vector Laboratories Inc.) for cyt-c as described by Babu et al. (12), and examined under the light microscope (magnification: 200x).

Endogenous peroxidase activity was quenched using $0.3 \%$ hydrogen peroxide in phosphate buffered saline (PBS) at room temperature for $30 \mathrm{~min}$, as described by Koçkaya et al. (13). The slides were reviewed independently by three observers. Intensity was assessed by comparison with the positive and negative control sections. All slides were photographed with the Olympus BX51 system light microscope (Tokyo, Japan) and photographs analysed using the Bs200prop software.

\section{Haematology and biochemistry}

Twenty-four hours after the final dosing, $5 \mathrm{~mL}$ of blood was collected from the heart before cervical dislocation in order to make the complete blood count with a Shimadzu MS59 blood counting device (Kyoto, Japan).

Serum was separated from blood samples after centrifugation at $1800 \mathrm{~g}$ for $15 \mathrm{~min}$ and analysed for urea, low density lipoprotein (LDL), high density lipoprotein (HDL), cholesterol (Chol), aspartate aminotransferase 
$(\mathrm{AST})$, alanine aminotransferase (ALT), and lactate dehydrogenase (LDH) activities using commercial biochemical kits (Audit Diagnostics, Cork, Ireland) on a Shimadzu CL-770 clinical spectrophotometer (Kyoto, Japan) according to the manufacturer's instructions.

\section{Statistical analyses}

For statistical analyses we used the SPSS Statistics 22 for Windows (IBM, New York, USA). Data are expressed as mean \pm standard error (SE) and statistical significance was set at $P \leq 0.05$. All measured parameters were analysed separately for male and female rats using the two-way analysis of variance (ANOVA).

\section{RESULTS AND DISCUSSION}

As the control group and vehicle control group did not differ in any of the parameters measured, the control group data are not presented in this paper for the sake of space and readability. No clinical signs of adverse effects were seen in rats and none died before the end of the study. Food and water consumption did not vary significantly across the groups (Table 1). The baseline mean body weights did not differ significantly between the groups or sexes. The final mean body weights were lower in the treated groups, but not significantly. However, body weight gain was significantly lower in the treated female rats than in the vehicle control females as opposed to the respective male groups, in which no significant differences in body weight gain were found. This may be because of hormone (gonadal hormone) or fat metabolism differences between the sexes.

Table 2 points to sex differences in variations in relative organ weights. Female rats in the fluconazole and low-dose $\mathrm{C}_{18} \mathrm{H}_{12} \mathrm{~S}_{2} \mathrm{IBr}$ group showed a significant increase in relative liver weight compared to the vehicle control, while male rats did not. The females in the low-dose $\mathrm{C}_{18} \mathrm{H}_{12} \mathrm{~S}_{2}$ IBr group also had significantly higher relative liver weight than the fluconazole group. In contrast, males did not significantly vary in relative liver weights.

Waxman and Holloway (14) reported that the expression of CYP P450 and other liver-expressed genes is sexually dimorphic and regulated by the levels of growth hormone in plasma, which is pulsatile in male animals and more frequent in female animals. This may explain the sex-based

Table 1 Food and water consumption and body weight measurements in the vehicle control and treated rats (mean $\pm S E$ )

\begin{tabular}{lcccc}
\hline & Vehicle control & Fluconazole & Low-dose $\mathbf{C}_{18} \mathbf{H}_{12} \mathbf{S}_{2} \mathbf{I B r}$ & High-dose $\mathbf{C}_{18} \mathbf{H}_{12} \mathbf{S}_{2} \mathbf{I B r}$ \\
\hline Baseline body weight & $112.38 \pm 6.0$ & $124.62 \pm 5.29$ & $124.12 \pm 4.30$ & $121.12 \pm 5.05$ \\
Final body weight & $145.37 \pm 6.11$ & $143.12 \pm 4.12$ & $140.37 \pm 4.18$ & $137.5 \pm 5.50$ \\
Weight gain (\%) & $30.16 \pm 3.58$ & $15.39 \pm 2.02^{\mathrm{a}}$ & $13.63 \pm 1.46^{\mathrm{a}}$ & $13.33 \pm 1.93^{\mathrm{a}}$ \\
Food consumption $\left(\mathrm{g} \mathrm{day}^{-1}\right)$ & $13.85 \pm 0.84$ & $12.05 \pm 0.48$ & $13.23 \pm 0.38$ & $13.86 \pm 0.42$ \\
Water consumption $\left(\mathrm{mL} \mathrm{day}^{-1}\right)$ & $35.36 \pm 2.27$ & $33.10 \pm 2.50$ & $36.13 \pm 1.61$ & $34.08 \pm 2.32$ \\
\hline & \multicolumn{4}{c}{ Male } \\
\hline Baseline body weight & $192.12 \pm 9.86$ & $174.87 \pm 7.35$ & $173.87 \pm 11.29$ & $157.5 \pm 11.79$ \\
Final body weight & $236 \pm 9.57$ & $206.37 \pm 7.69$ & $213.5 \pm 6.57$ & $198.25 \pm 10.53$ \\
Weight gain (\%) & $23.51 \pm 3.10$ & $18.36 \pm 2.49$ & $27.81 \pm 5.10$ & $25.49 \pm 6.20$ \\
Food consumption $\left(\mathrm{g} \mathrm{day}^{-1}\right)$ & $17.39 \pm 0.91$ & $17.57 \pm 0.32$ & $16.14 \pm 0.65$ & $16.72 \pm 0.57$ \\
Water consumption $\left(\mathrm{mL} \mathrm{day}^{-1}\right)$ & $37.68 \pm 3.17$ & $35.39 \pm 1.19$ & $36.67 \pm 2.99$ & $37.44 \pm 3.63$ \\
\hline
\end{tabular}

${ }^{a}$ Statistically significant difference from the vehicle control group $(\mathrm{P} \leq 0.05)$

Table 2 Relative organ weights (mean $\pm S E$ ) in the vehicle control and treated rats

\begin{tabular}{lcccc}
\hline Relative organ weight & Vehicle control & Fluconazole & Low-dose $\mathbf{C}_{18} \mathbf{H}_{12} \mathbf{S}_{2} \mathbf{I B r}$ & High-dose $\mathbf{C}_{18} \mathbf{H}_{12} \mathbf{S}_{2} \mathbf{I B r}$ \\
\hline Liver & $3.22 \pm 0.10$ & $3.70 \pm 0.06^{\mathrm{a}}$ & $4.10 \pm 0.13^{\mathrm{a}, \mathrm{b}}$ & $3.59 \pm 0.20$ \\
Kidney & $0.36 \pm 0.006$ & $0.35 \pm 0.007$ & $0.39 \pm 0.013$ & $0.34 \pm 0.015^{\mathrm{c}}$ \\
Thymus & $0.23 \pm 0.011$ & $0.19 \pm 0.012$ & $0.25 \pm 0.014^{\mathrm{b}}$ & $0.22 \pm 0.013$ \\
Spleen & $0.18 \pm 0.007$ & $0.23 \pm 0.015^{\mathrm{a}}$ & $0.28 \pm 0.006^{\mathrm{a}}$ & $0.23 \pm 0.005^{\mathrm{a}}$ \\
\hline & \multicolumn{4}{c}{ Male } \\
\hline Liver & $2.88 \pm 0.16$ & $2.74 \pm 0.05$ & $2.85 \pm 0.05$ & $2.63 \pm 0.07$ \\
Kidney & $0.32 \pm 0.018$ & $0.32 \pm 0.005$ & $0.34 \pm 0.008$ & $0.31 \pm 0.007^{\mathrm{c}}$ \\
Thymus & $0.11 \pm 0.008$ & $0.12 \pm 0.009$ & $0.12 \pm 0.009$ & $0.12 \pm 0.012$ \\
Spleen & $0.15 \pm 0.007$ & $0.17 \pm 0.011^{\mathrm{a}}$ & $0.20 \pm 0.012^{\mathrm{a}}$ & $0.19 \pm 0.010^{\mathrm{a}}$ \\
\hline
\end{tabular}

astatistically significant difference from the vehicle control group $(\mathrm{P} \leq 0.05)$

${ }^{b}$ Statistically significant difference from the fluconazole group $(\mathrm{P} \leq 0.05)$

'Statistically significant difference from the low-dose $C_{18} H_{12} S_{2} I B r$ group $(\mathrm{P} \leq 0.05)$ 
differences in drug metabolism and pharmacokinetics in the liver of the fluconazole and $\mathrm{C}_{18} \mathrm{H}_{12} \mathrm{~S}_{2} \mathrm{IBr}$-treated groups.

The lower relative kidney weight in the high-dose $\mathrm{C}_{18} \mathrm{H}_{12} \mathrm{~S}_{2}$ IBr group compared to vehicle control corresponds to the lower glomerular diameters and volume.

Relative spleen weights increased significantly in all treated groups compared to the vehicle control, regardless of sex. As, according to Sellers et al. (15), spleen and thymus weights tend to change naturally, we took into account histopathological changes in these organs and observed an increase in the number of megakaryocytes in the low-dose $\mathrm{C}_{18} \mathrm{H}_{12} \mathrm{~S}_{2} \mathrm{IBr}$ group. A similar finding in mice was observed by Fortoul et al. (16). Our organ weight results were consistent with the histological findings, including megakaryocyte increase. Greater relative spleen weight may be attributed to fibrosis and increase in megakaryocyte count in the spleen, probably induced by fluconazole or $\mathrm{C}_{18} \mathrm{H}_{12} \mathrm{~S}_{2} \mathrm{IBr}$ treatment.

Table 3 shows haematological variations between the groups. Fluconazole significantly increased leukocytes and lowered neutrophils whereas $\mathrm{C}_{18} \mathrm{H}_{12} \mathrm{~S}_{2} \mathrm{IBr}$ did not. This may point to fluconazole's greater toxicity. Fluconazole is known to lower the expression of various cytokine genes because of its lipophilic character (17). The increased glomerular diameter and volume in the fluconazole group seem to confirm the migration of neutrophils (18). As for other haematological parameters, all treatments had similar effects, and we saw no differences between fluconazole and $\mathrm{C}_{18} \mathrm{H}_{12} \mathrm{~S}_{2} \mathrm{IBr}$ in respect to the vehicle control. It may be interesting to note that the pattern of variations was similar between the sexes: the same values rose or dropped in the same groups, regardless of the sex even though the doses received may have resulted in higher drug concentrations in female rats because of the lower clearance or small volume distribution in female tissues due to different body composition and organ mass.

Table 4 shows the results of the biochemical analysis in serum samples. Even though ALT and LDH differed between the fluconazole and $\mathrm{C}_{18} \mathrm{H}_{12} \mathrm{~S}_{2} \mathrm{IBr}$ groups, which may indicate a moderate hepatic injury with leakage of liver enzymes, no significant changes were observed in other liver enzyme levels, and the new drug did not cause significant changes in respect to control, except for LDL.

Glomerular variations (Table 5) showed the opposite effects between fluconazole and $\mathrm{C}_{18} \mathrm{H}_{12} \mathrm{~S}_{2} \mathrm{IBr}$. Glomerular hypertrophy may be associated with hyperfiltration and thickening of the glomerular basement membrane after fluconazole treatment. In the $\mathrm{C}_{18} \mathrm{H}_{12} \mathrm{~S}_{2} \mathrm{IBr}$ groups, lower glomerular volume may reflect inadequate filtration, kidney failure, and chronic kidney disease. Both changes are not favourable for kidney function but other parameters such as relative weight, histopathology, and biochemistry did not point to significant changes in the kidney.

Histopathology showed that $\mathrm{C}_{18} \mathrm{H}_{12} \mathrm{~S}_{2} \mathrm{IBr}$ and fluconazole did not cause any significant changes in the liver, lymph nodes, and kidney tissues (Figure 2). Minor histopathological changes in the thymus and spleen (Figures 3, 4) were comparable between the fluconazole and $\mathrm{C}_{18} \mathrm{H}_{12} \mathrm{~S}_{2} \mathrm{IBr}$ treated groups and may be explained as a mechanism for countering the toxic effects of fluconazole and $\mathrm{C}_{18} \mathrm{H}_{12} \mathrm{~S}_{2} \mathrm{IBr}$.

Cyt-c as a marker of liver and kidney injury in vivo has been investigated by several studies and can be used to predict drug-induced hepatotoxicity $(19,20)$. Figure 5 shows more cyt-c positive hepatocytes in the $\mathrm{C}_{18} \mathrm{H}_{12} \mathrm{~S}_{2} \mathrm{IBr}-$ treated groups than in the fluconazole group. The effect of the new drug seems dose-dependent and suggests an

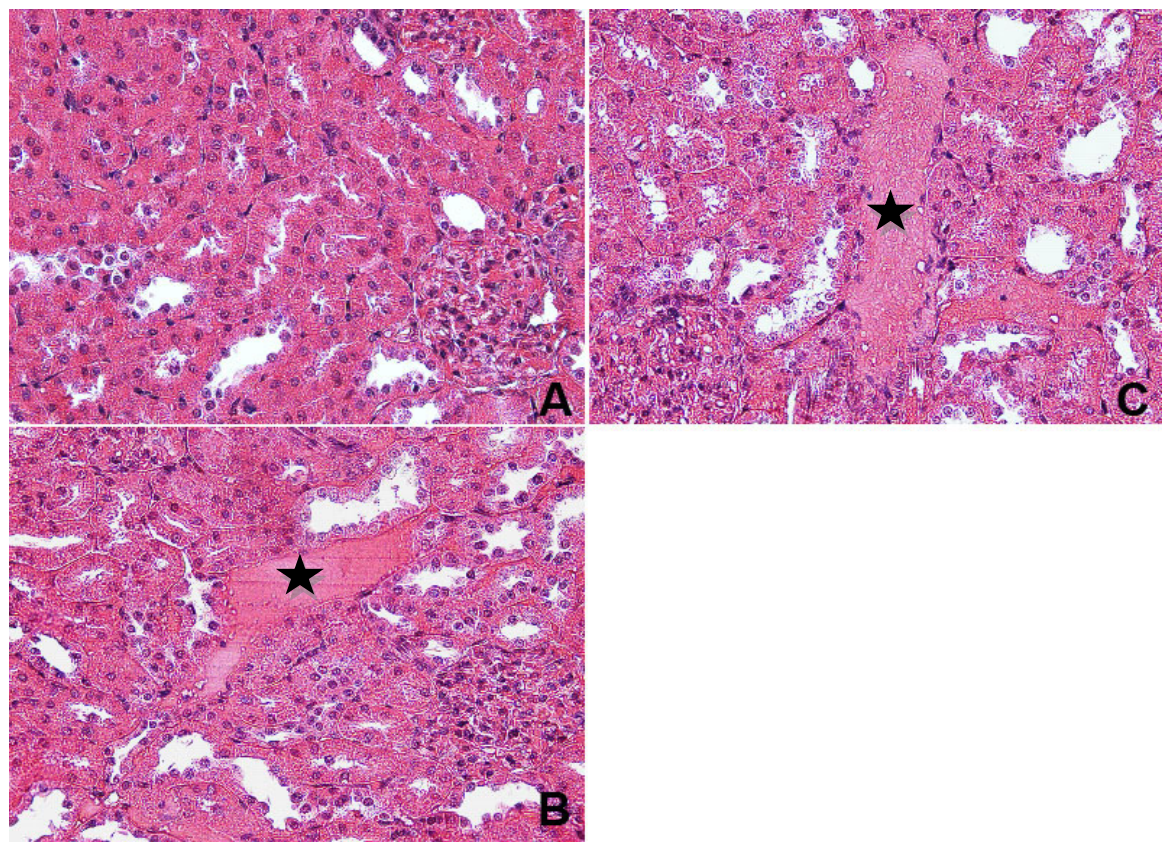

Figure 2 Kidney tissues stained with haematoxylin and eosin. A. Vehicle control group, B. Congestion in the low-dose $C_{18} H_{12} S_{2} I B r$ group (asterisk). C. Congestion in the high-dose $\mathrm{C}_{18} \mathrm{H}_{12} \mathrm{~S}_{2} \mathrm{IBr}$ group (asterisk); magnification $200 x$ 
Table 3 Haematological findings in the vehicle control and treated rats (mean $\pm S E$ )

\begin{tabular}{|c|c|c|c|c|}
\hline & Vehicle control & Fluconazole & $\begin{array}{l}\text { Low-dose } \\
\mathrm{C}_{18} \mathrm{H}_{12} \mathrm{~S}_{2} \mathrm{IBr}\end{array}$ & $\begin{array}{l}\text { High-dose } \\
\mathrm{C}_{18} \mathrm{H}_{12} \mathrm{~S}_{2} \mathrm{IBr}\end{array}$ \\
\hline & \multicolumn{4}{|c|}{ Female } \\
\hline \multicolumn{5}{|l|}{ Leukocytes } \\
\hline White Blood Cell $\left(\mathrm{mm}^{-3}\right)$ & $3.06 \pm 0.43$ & $4.94 \pm 0.29^{\mathrm{a}}$ & $4.10 \pm 0.41$ & $4.13 \pm 0.20^{\mathrm{b}}$ \\
\hline Lymphocyte \% & $74.48 \pm 1.60$ & $85.67 \pm 1.38^{\mathrm{a}}$ & $85.06 \pm 1.24^{\mathrm{a}}$ & $81.15 \pm 2.21^{\mathrm{a}}$ \\
\hline Monocyte \% & $7.06 \pm 0.47$ & $4.41 \pm 0.17$ & $5.35 \pm 0.21$ & $6.26 \pm 0.51$ \\
\hline Neutrophil \% & $10.01 \pm 1.13$ & $5.76 \pm 0.56^{\mathrm{a}}$ & $8.36 \pm 0.67$ & $9.66 \pm 1.04$ \\
\hline Eosinophil \% & $2.48 \pm 1.49$ & $0.90 \pm 0.52$ & $0.41 \pm 0.33$ & $0.52 \pm 0.29$ \\
\hline Basophil \% & $0.40 \pm 0.05$ & $0.35 \pm 0.02$ & $0.33 \pm 0.02$ & $0.48 \pm 0.06$ \\
\hline \multicolumn{5}{|l|}{ Erythrocytes } \\
\hline Red Blood Cells $\left(\mathrm{mm}^{-3}\right)$ & $7.42 \pm 0.23$ & $6.56 \pm 0.29$ & $7.02 \pm 0.08$ & $6.35 \pm 0.30$ \\
\hline MCV (Mean Corpuscular Volume) & $47.91 \pm 0.90$ & $54.92 \pm 0.52^{\mathrm{a}}$ & $56.47 \pm 0.94^{\mathrm{a}}$ & $58.16 \pm 0.24^{\mathrm{a}}$ \\
\hline HCT (Haematocrit) & $35.47 \pm 0.87$ & $36.48 \pm 1.37$ & $39.60 \pm 0.94$ & $38.62 \pm 0.53$ \\
\hline MCH (Mean Corpuscular Haemoglobin) & $18.98 \pm 0.40$ & $17.02 \pm 0.14^{\mathrm{a}}$ & $16.45 \pm 0.12^{\mathrm{a}}$ & $17.57 \pm 0.34^{\mathrm{a}}$ \\
\hline MCHC (Mean Corpuscular Haemoglobin Concentration) & $40.41 \pm 0.30$ & $31.01 \pm 0.24^{\mathrm{a}}$ & $30.67 \pm 1.41^{\mathrm{a}}$ & $29.97 \pm 0.54^{\mathrm{a}}$ \\
\hline Hb (Haemoglobin) & $35.08 \pm 0.40$ & $11.20 \pm 0.51^{\mathrm{a}}$ & $11.35 \pm 0.30^{\mathrm{a}}$ & $11.46 \pm 0.21^{\mathrm{a}}$ \\
\hline $\begin{array}{l}\text { RDW-SD (Red Cell Distribution Width-Standard } \\
\text { deviation) }\end{array}$ & $35.08 \pm 0.40$ & $36.48 \pm 0.43^{\mathrm{a}}$ & $36.56 \pm 0.56^{\mathrm{a}}$ & $38.01 \pm 0.81^{\mathrm{a}}$ \\
\hline $\begin{array}{l}\text { RDW-CV(Red Cell Distribution Width-Coefficient } \\
\text { variation) }\end{array}$ & $19.91 \pm 0.27$ & $18.03 \pm 0.28^{\mathrm{a}}$ & $17.60 \pm 0.32^{\mathrm{a}}$ & $17.72 \pm 0.38^{\mathrm{a}}$ \\
\hline \multicolumn{5}{|l|}{ Thrombocytes } \\
\hline Thrombocyte $\left(\mathrm{mm}^{-3}\right)$ & $742.00 \pm 16.12$ & $635.00 \pm 74.33$ & $793.37 \pm 33.60$ & $763.37 \pm 55.2$ \\
\hline MPV (Mean Platelet Volume) & $5.86 \pm 0.15$ & $5.91 \pm 0.28$ & $5.80 \pm 0.21$ & $5.76 \pm 0.06$ \\
\hline \multirow[t]{2}{*}{ PDW (index of thrombocytes heterogeneity) } & $9.92 \pm 0.48$ & $8.37 \pm 0.28$ & $8.07 \pm 0.21$ & $8.40 \pm 0.27$ \\
\hline & \multicolumn{4}{|c|}{ Male } \\
\hline \multicolumn{5}{|l|}{ Leukocytes } \\
\hline White Blood Cell $\left(\mathrm{mm}^{-3}\right)$ & $3.86 \pm 034$ & $5.04 \pm 0.38^{\mathrm{a}}$ & $3.50 \pm 0.27$ & $3.54 \pm 0.20$ \\
\hline Lymphocyte \% & $72.87 \pm 1.37$ & $79.61 \pm 0.96^{\mathrm{a}}$ & $79.83 \pm 1.72^{\mathrm{a}}$ & $77.92 \pm 1.94^{\mathrm{a}}$ \\
\hline Monocyte \% & $6.18 \pm 0.45$ & $6.41 \pm 0.23$ & $6.57 \pm 0.37$ & $6.80 \pm 0.21$ \\
\hline Neutrophil \% & $13.65 \pm 0.93$ & $9.65 \pm 0.69^{\mathrm{a}}$ & $11.33 \pm 1.13$ & $11.41 \pm 0.74$ \\
\hline Eosinophil \% & $1.15 \pm 0.39$ & $1.08 \pm 0.44$ & $0.51 \pm 0.34$ & $1.10 \pm 0.60$ \\
\hline Basophil \% & $0.35 \pm 0.05$ & $0.43 \pm 0.04$ & $0.45 \pm 0.06$ & $0.33 \pm 0.03$ \\
\hline \multicolumn{5}{|l|}{ Erythrocytes } \\
\hline Red Blood Cell $\left(\mathrm{mm}^{-3}\right)$ & $8.60 \pm 0.18$ & $8.37 \pm 0.17$ & $8.23 \pm 0.13$ & $7.90 \pm 0.19$ \\
\hline MCV (Mean Corpuscular Volume) & $46.83 \pm 0.76$ & $55.85 \pm 0.46^{\mathrm{a}}$ & $52.1 \pm 0.47^{\mathrm{a}}$ & $54.9 \pm 0.74^{\mathrm{a}}$ \\
\hline HCT (Haematocrit) & $40.33 \pm 1.26$ & $46.75 \pm 0.92$ & $42.83 \pm 0.61$ & $43.31 \pm 0.96$ \\
\hline MCH (Mean Corpuscular Haemoglobin) & $18.17 \pm 0.24$ & $16.72 \pm 0.25^{\mathrm{a}}$ & $16.58 \pm 0.28^{\mathrm{a}}$ & $16.91 \pm 0.18^{\mathrm{a}}$ \\
\hline MCHC (Mean Corpuscular Haemoglobin Concentration) & $38.42 \pm 0.53$ & $29.93 \pm 0.45^{\mathrm{a}}$ & $31.85 \pm 0.37^{\mathrm{a}}$ & $30.48 \pm 0.23^{\mathrm{a}}$ \\
\hline $\mathrm{Hb}$ (Haemoglobin) & $35.33 \pm 0.28$ & $14.00 \pm 0.27^{\mathrm{a}}$ & $13.62 \pm 0.15^{\mathrm{a}}$ & $13.20 \pm 0.31^{\mathrm{a}}$ \\
\hline $\begin{array}{l}\text { RDW-SD (Red Cell Distribution Width-Standard } \\
\text { deviation) }\end{array}$ & $35.33 \pm 0.28$ & $39.26 \pm 0.11^{\mathrm{a}}$ & $37.75 \pm 0.23^{\mathrm{a}}$ & $39.28 \pm 0.28^{\mathrm{a}}$ \\
\hline $\begin{array}{l}\text { RDW-CV(Red Cell Distribution Width-Coefficient } \\
\text { variation) }\end{array}$ & $20.52 \pm 0.31$ & $17.41 \pm 1.16^{\mathrm{a}}$ & $19.67 \pm 0.10^{\mathrm{a}}$ & $19.43 \pm 0.15^{\mathrm{a}}$ \\
\hline \multicolumn{5}{|l|}{ Thrombocytes } \\
\hline Thrombocyte $\left(\mathrm{mm}^{-3}\right)$ & $607.00 \pm 78.07$ & $732.12 \pm 29.35$ & $711.50 \pm 32.62$ & $806.37 \pm 24.96$ \\
\hline MPV (Mean Platelet Volume) & $7.21 \pm 0.41$ & $5.86 \pm 0.05$ & $5.76 \pm 0.11$ & $6.06 \pm 0.30$ \\
\hline PDW (index of thrombocyte heterogeneity) & $11.31 \pm 0.31$ & $8.61 \pm 0.10$ & $8.76 \pm 0.17$ & $8.75 \pm 0.39$ \\
\hline
\end{tabular}

astatistically significant difference from the vehicle control group $(\mathrm{P} \leq 0.05)$

${ }^{b}$ Statistically significant difference from the fluconazole group $(\mathrm{P} \leq 0.05)$ 
Table 4 Blood biochemistry in the vehicle control and treated rats (mean $\pm S E$ )

\begin{tabular}{|c|c|c|c|c|}
\hline & Vehicle control & Fluconazole & $\begin{array}{c}\text { Low-dose } \\
\mathrm{C}_{18} \mathrm{H}_{12} \mathrm{~S}_{2} \mathrm{IBr}\end{array}$ & $\begin{array}{c}\text { High-dose } \\
\mathrm{C}_{18} \mathrm{H}_{12} \mathrm{~S}_{2} \mathrm{IBr}\end{array}$ \\
\hline \multicolumn{5}{|c|}{ Female } \\
\hline $\operatorname{AST}\left(\mathrm{IU} \mathrm{L}^{-1}\right)$ & $173.31 \pm 4.49$ & $161.75 \pm 14.91$ & $252.57 \pm 23.96$ & $219.67 \pm 21.17$ \\
\hline $\operatorname{ALT}\left(\mathrm{IU} \mathrm{L}^{-1}\right)$ & $57.25 \pm 2.82$ & $57.03 \pm 3.43$ & $75.41 \pm 1.30^{\mathrm{b}}$ & $68.18 \pm 4.11$ \\
\hline $\mathrm{LDL}\left(\mathrm{mg} \mathrm{dL}^{-1}\right)$ & $33.52 \pm 3.94$ & $33.28 \pm 1.10$ & $39.98 \pm 1.71^{\mathrm{a}, \mathrm{c}}$ & $30.90 \pm 0.96$ \\
\hline $\mathrm{HDL}\left(\mathrm{mg} \mathrm{dL}^{-1}\right)$ & $53.04 \pm 1.95$ & $46.70 \pm 2.77$ & $48.53 \pm 2.38$ & $44.08 \pm 1.56$ \\
\hline Chol (mg dL $\left.{ }^{-1}\right)$ & $64.55 \pm 4.35$ & $64.20 \pm 7.00$ & $58.98 \pm 7.13$ & $49.96 \pm 5.34$ \\
\hline LDH $\left(\mathrm{IUL}^{-1}\right)$ & $2817.83 \pm 344.21$ & $1958.50 \pm 166.12^{\mathrm{a}}$ & $4858.12 \pm 325.06^{\mathrm{b}}$ & $3666.50 \pm 275.17^{b}$ \\
\hline Urea $\left(\mathrm{mg} \mathrm{dL}^{-1}\right)$ & $53.41 \pm 2.94$ & $55.75 \pm 2.51$ & $62.00 \pm 3.33$ & $53.62 \pm 3.13$ \\
\hline \multicolumn{5}{|c|}{ Male } \\
\hline AST (IU L L) & $236.38 \pm 20.93$ & $217.73 \pm 9.33$ & $226.12 \pm 12.47$ & $250.77 \pm 17.67$ \\
\hline ALT (IU L $\left.{ }^{-1}\right)$ & $59.48 \pm 3.55$ & $51.36 \pm 3.59$ & $62.07 \pm 3.42^{\mathrm{b}}$ & $57.76 \pm 5.15$ \\
\hline LDL (mg dL $\left.{ }^{-1}\right)$ & $30.90 \pm 0.20$ & $38.80 \pm 1.67$ & $42.91 \pm 2.63^{\mathrm{a}, \mathrm{c}}$ & $37.20 \pm 0.63$ \\
\hline $\mathrm{HDL}\left(\mathrm{mg} \mathrm{dL}^{-1}\right)$ & $44.00 \pm 2.31$ & $45.44 \pm 3.57$ & $50.26 \pm 3.68$ & $41.38 \pm 4.28$ \\
\hline Chol (mg dL $\left.{ }^{-1}\right)$ & $55.91 \pm 3.12$ & $66.52 \pm 5.74$ & $51.46 \pm 7.26$ & $64.35 \pm 7.80$ \\
\hline $\mathrm{LDH}\left(\mathrm{IU} \mathrm{L}^{-1}\right)$ & $5419.37 \pm 432.95$ & $3206.62 \pm 402.39^{\mathrm{a}}$ & $5419.00 \pm 590.95^{\mathrm{b}}$ & $5155.50 \pm 526.64^{b}$ \\
\hline Urea $\left(\mathrm{mg} \mathrm{dL}^{-1}\right)$ & $55.00 \pm 3.36$ & $47.50 \pm 2.62$ & $46.12 \pm 3.76$ & $47.85 \pm 3.60$ \\
\hline
\end{tabular}

${ }^{a}$ Statistically significant difference from the vehicle control group $(\mathrm{P} \leq 0.05)$

${ }^{b}$ Statistically significant difference from the fuconazole group $(\mathrm{P} \leq 0.05)$

'Statistically significant difference from the high-dose $C_{18} H_{12} S_{2} I B r$ group $(\mathrm{P} \leq 0.05)$
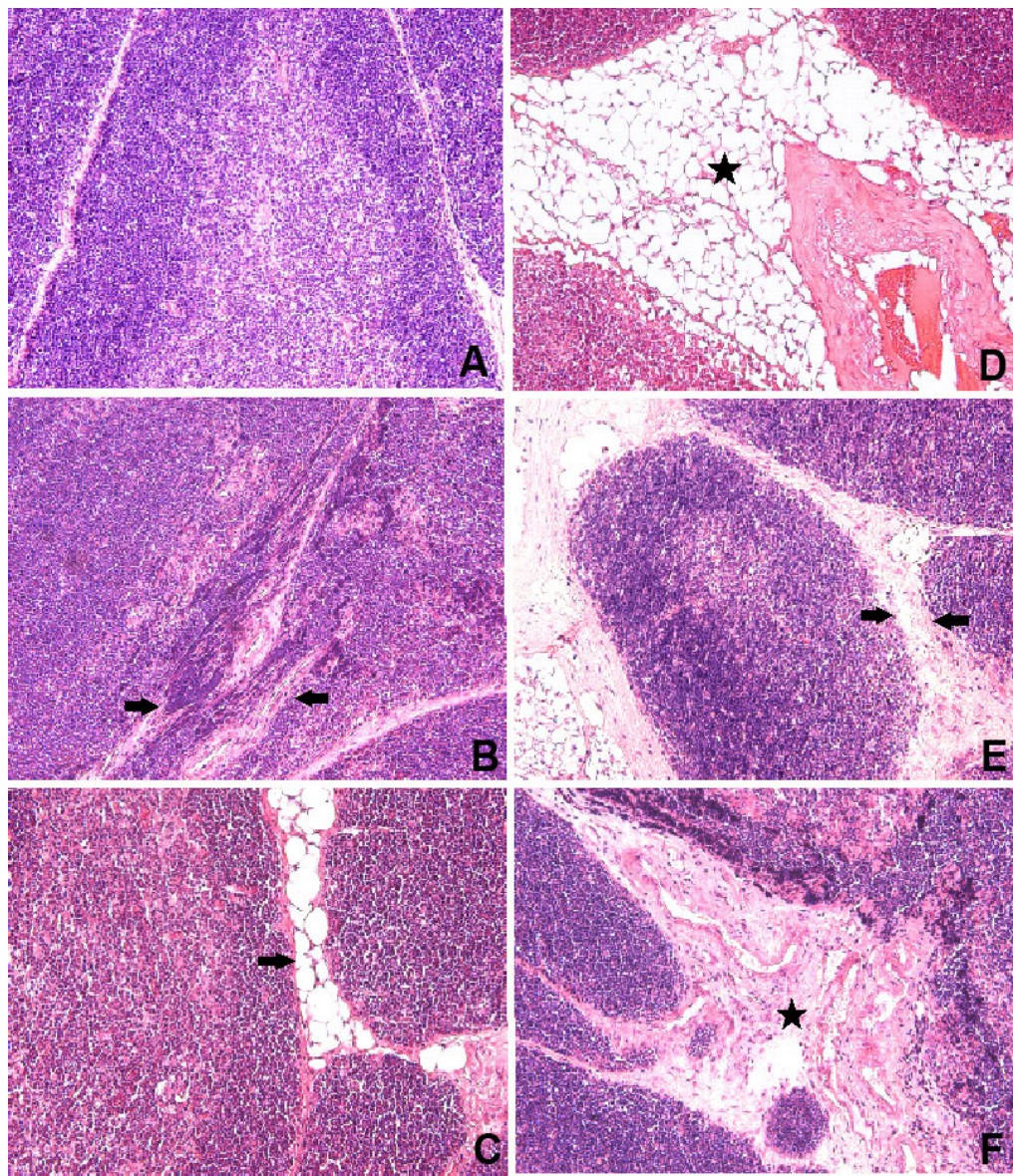

Figure 3 Thymus tissues stained with haematoxylin and eosin. A. Vehicle control group B. Fibrosis (arrow) in the fluconazole group, $\boldsymbol{C}$. Increases in the fat cells of the connective tissue in the fluconazole group (arrow). D. Increases in the fat cells of the connective tissue (asterisk) in the low-dose $\mathrm{C}_{18} \mathrm{H}_{12} \mathrm{~S}_{2} \mathrm{IBr}$ group. $\boldsymbol{E}$. Enlargement of the interstitial connective tissue in the low-dose $\mathrm{C}_{18} \mathrm{H}_{12} \mathrm{~S}_{2} \mathrm{IBr}$ group (arrow). F. Fibrosis in the high-dose $\mathrm{C}_{18} \mathrm{H}_{12} \mathrm{~S}_{2} \mathrm{IBr}$ group (asterisk); magnification 100x 

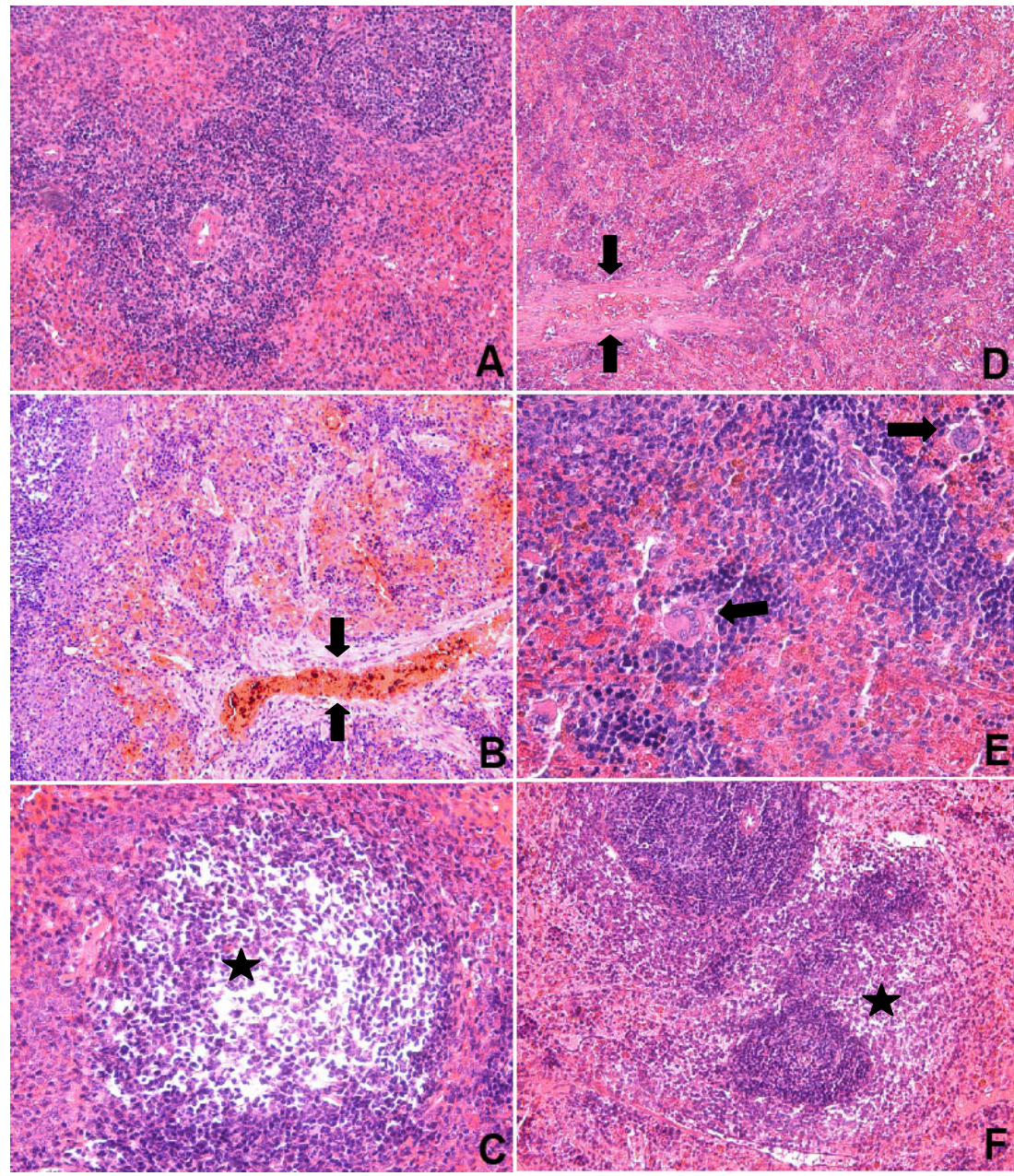

Figure 4 Spleen tissues stained with haematoxylin and eosin. A. Vehicle control group; magnification 100x. B. Fibrosis in the fluconazole group (arrow), $\boldsymbol{C}$. Lymphocyte depletion in the white pulp in the fluconazole group (asterisk); magnification 200x. D. Fibrosis (arrow) in the low-dose $C_{18} H_{1} S_{2} I B r$ group, $\boldsymbol{E}$. Increase in megakaryocyte count in the low-dose $\mathrm{C}_{18} \mathrm{H}_{12} \mathrm{~S}$ IBr group (arrow); magnification 200x. $\stackrel{F}{\mathrm{~F}}$. Lymphocyte depletion in the white pulp in the high-dose $\mathrm{C}_{18} \mathrm{H}_{12} \mathrm{~S}$ IBr group (asterisk); magnification 100x

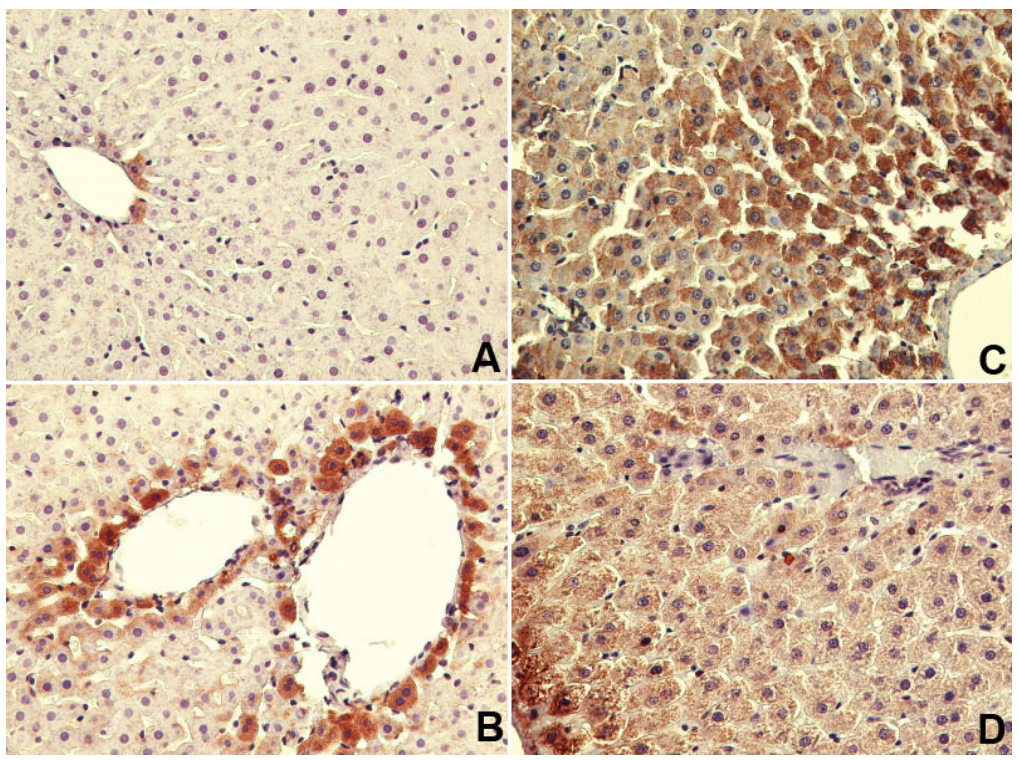

Figure 5 Immunolocalisation of cyt-c in perivenular, midzonal, or periportal hepatocytes in the liver sections. Cyt-c positive cells (brown) $\boldsymbol{A}$. in the vehicle control group, $\boldsymbol{B}$. in the fluconazole group (arrow), $\boldsymbol{C}$. In the low-dose $\mathrm{C}_{18} \mathrm{H}_{12} \mathrm{~S}_{2} \mathrm{IBr}$ group, D. in the high-dose $\mathrm{C}_{18} \mathrm{H}_{12} \mathrm{~S}_{2} \mathrm{IBr}$ group; magnification $200 x$ 
Table 5 Glomerular measurements in the vehicle control and treated rats (mean $\pm S E$ )

\begin{tabular}{|c|c|c|c|}
\hline \multirow[t]{2}{*}{ Groups } & \multicolumn{2}{|c|}{ Diameter of glomerulus } & \multirow[t]{2}{*}{ Glomerular volume $\left(1^{3} \mu^{-3}\right)$} \\
\hline & $\mathbf{x}$ axis & y axis & \\
\hline Vehicle control & $65.23 \pm 0.89$ & $81.83 \pm 1.34$ & $218.36 \pm 8.76$ \\
\hline Fluconazole & $69.58 \pm 0.94^{\mathrm{a}}$ & $86.64 \pm 1.37$ & $262.26 \pm 11.06^{\mathrm{a}}$ \\
\hline Low-dose $\mathrm{C}_{18} \mathrm{H}_{12} \mathrm{~S}_{2} \mathrm{IBr}$ & $62.43 \pm 1.0^{\mathrm{b}}$ & $75.92 \pm 1.23^{\mathrm{a}, \mathrm{b}}$ & $184.17 \pm 7.88^{\mathrm{a}, \mathrm{b}}$ \\
\hline High-dose $\mathrm{C}_{18} \mathrm{H}_{12} \mathrm{~S}_{2} \mathrm{IBr}$ & $59.40 \pm 0.97^{\mathrm{a}, \mathrm{b}}$ & $79.13 \pm 1.51^{\mathrm{b}}$ & $186.32 \pm 8.30^{\mathrm{b}}$ \\
\hline
\end{tabular}

${ }^{a}$ Statistically significant difference from the vehicle control group $(\mathrm{P} \leq 0.05)$

${ }^{b}$ Statistically significant difference from the fluconazole group $(\mathrm{P} \leq 0.05)$

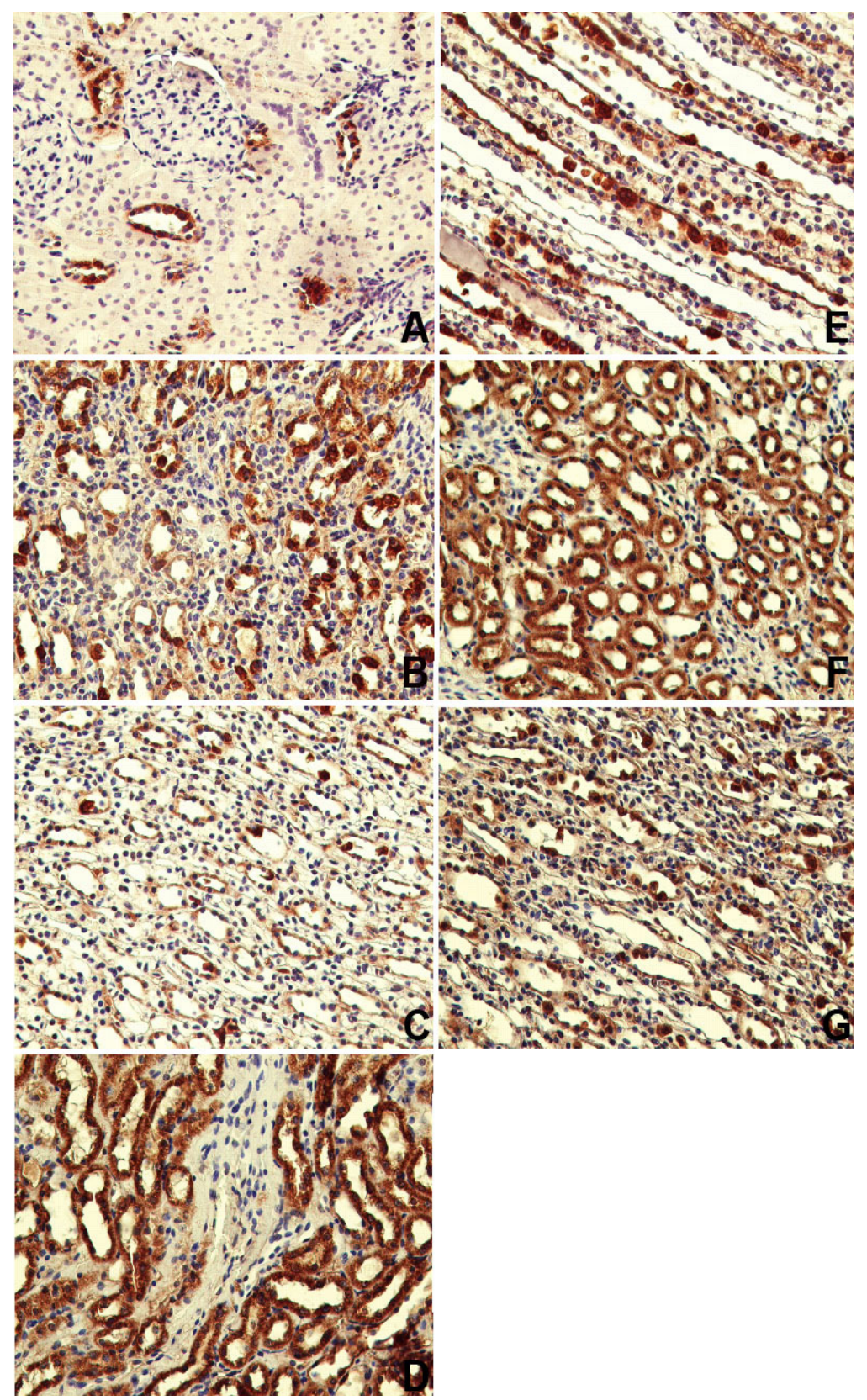

Figure 6 Immunolocalisation of cyt-c in the kidney sections. Cyt-c positive cells (brown) A. in the proximal tubules and some distal tubules of the kidney cortex in the vehicle control group. B. Cortex, $\boldsymbol{C}$. Medulla of the kidney in the fluconazole group. D. Cortex, $\boldsymbol{E}$. Medulla of the kidney in the low-dose $\mathrm{C}_{18} \mathrm{H}_{2} \mathrm{~S}_{2} \mathrm{IBr}$ group. Greater cyt-c-positive cell staining (brown) F. Cortex, G. Medulla of the kidney in the high-dose $C_{18} H_{12} S_{2} I B r$ group; magnification $200 x$ 
increase in the number of apoptotic cells. However, as these changes did not exactly match the biochemical and histopathological findings as the key indicators of liver injury, it is hard to claim that $\mathrm{C}_{18} \mathrm{H}_{12} \mathrm{~S}_{2} \mathrm{IBr}$ induced liver toxicity.

Figure 6 compares immunolocalisation of cyt-c in the kidney between the vehicle control and treatment groups. Greater staining in the $\mathrm{C}_{18} \mathrm{H}_{12} \mathrm{~S}_{2} \mathrm{IBr}$-treated groups compared to fluconazole group points to greater apoptotic effect.

\section{CONCLUSION}

This study was the first to test the newly synthesised thialo benzene derivative $\mathrm{C}_{18} \mathrm{H}_{12} \mathrm{~S}_{2} \mathrm{IBr}$ in mammals in vivo and to compare it to the conventional anti-fungal drug fluconazole. Considering that $\mathrm{C}_{18} \mathrm{H}_{12} \mathrm{~S}_{2} \mathrm{IBr}$ is more active at lower concentrations and has comparable toxic effects to fluconazole in rats, this new compound shows some promise in the treatment of fungal infections. Future, more detailed animal studies are needed, that will include drug interactions and molecular toxicity pathways. If the results are promising, clinical studies should follow.

\section{Conflict of interest}

The authors declare no conflict of interest.

\section{REFERENCES}

1. Infectious Diseases Society of America. Statement of the IDSA concerning Bioshield II: Responding to an everchanging threat'. Alexandria, VA: IDSA; 2004.

2. Sun QY, Zhang WN, Xu JM, Cao YB, Wu QY, Zhang DZ, Liu CM, Yu SC, Jiang YY. Synthesis and evaluation of novel 1-(1H-1,2,4-triazol-1-yl)-2-(2,4-difluorophenyl)-3-[(4substitutedphenyl)-piperazin-1-yl]-propan-2-ols as antifungal agents. Eur J Med Chem 2007;42:1151-7. doi: 10.1016/j.ejmech.2006.11.003

3. Hilley Vensel TD. Fluconazole: a valuable fungistatic. Primary Car Update for OB/GYNS 2002;9:181-3. doi: 10.1016/S1068-607X(02)00115-4

4. Loğoğlu E, Arslan S, Öktemer A. In vitro biological activity studies of thioethoxy- and thiophyenoxyhalobenzene derivatives. Heterocycl Comm 2006;12:219-24. doi: 10.1515/HC.2006.12.3-4.219

5. Süloğlu AK, Karacaoğlu E, Koçkaya EA, Selmanoğlu G, Loğoğlu E. Cytotoxic effects of a novel thialo benzene derivative 2,4-dithiophenoxy-1-Iodo-4-bromo benzene $\left(\mathrm{C}_{18} \mathrm{H}_{12} \mathrm{~S}\right.$ IB $)$ in L929 cells. Int J Toxicol 2014;33:319-24. doi: $10.1177 / 1091581814530437$

6. Food and Drug Administration (FDA). DIFLUCAN ${ }^{\circledR}$ (Fluconazole Tablets) (Fluconazole for Oral Suspension) [displayed 2 March 2015]. Available at http://www. a c c e s s d a ta.fda.gov/drugsatfda_docs/ label/2014/019949s060,020090s044lbl.pdf
7. Park K, Williams DP, Naisbitt DJ, Kitteringham NR, Pirmohamed M. Investigation of toxic metabolites during drug development. Toxicol Appl Pharmacol 2005;207(Suppl 2):425-34. PMID: 15996699

8. Joly V, Bolard J, Yeni P. In vitro models for studying toxicity of antifungal agents. Antimicrob Agents Chemother 1992;36:1799-804. PMC 192189

9. National Research Council. Guide for the Care and Use of Laboratory Animals. Eighth edition, 2011 [displayed 13 February 2015]. Available at http:/grants.nih.gov/grants/ olaw/Guide-for-the-care-and-use-of-laboratory-animals.pdf

10. Pappas PG, Rex JH, Sobel JD, Filler SG, Dismukes WE, Walsh TJ, Edwards JE. Guidelines for treatment of Candidiasis. Clin Infect Dis 2004;38:161-89. doi: 10.1086/380796

11. Kılıç A, Akay MT. A three generation study with genetically modified Bt corn in rats: Biochemical and histopathological investigation. Food Chem Toxicol 2008;46:1164-70. doi: 10.1016/j.fct.2007.11.016

12. Babu PP, Yoshida Y, Su M, Segura M, Kawamura S, Yasui N. Immunohistochemical expression of Bcl-2, Bax and cytochrome $\mathrm{c}$ following focal cerebral ischemia and effect of hypothermia in rat. Neurosci Lett 2000;291:196-200. PMID: 10984640

13. Koçkaya EA, Kılıç Süloğlu A, Karacaoğlu E, Selmanoğlu G. Vinclozolin Exposure throughout pregnancy and its developmental toxicity. Toxicol Res 2014;3:375-83. doi: 10.1039/C4TX00037D

14. Waxman DJ, Holloway MG. Sex differences in the expression of hepatic drug metabolizing enzymes. Mol Pharmacol 2009;76:215-28. doi: 10.1124/mol.109.056705

15. Sellers RS, Morton D, Michael B, Roome N, Johnson J.K, Yano BL, Perry R, Schafer K. Society of Toxicologic Pathology Position Paper: Organ weight recomendations for toxicology studies. Toxicol Pathol 2007;35:751-5. PMID: 17849358

16. Fortoul TI, Piñón-Zarate G, Diaz-Bech ME, GonzálezVillalva A, Mussali-Galante P, Rodriguez-Lara V, ColinBarenque L, Martinez-Pedraza M, Montaño LF. Spleen and bone marrow megakaryocytes as targets as targets for inhaled vanadium. Histol Histopathol 2008;23:1321-6. PMID: 18785114

17. Benko I, Hernadi F, Megyeri A, Kiss A, Somogyi G, Tegyey Z, Kraicsovits F, Kovács P. Comparison of the toxicity of fluconazole and other azole antifungal drugs to murine and human granulocyte-macrophage progenitor cells in vitro. J Antimicrob Chemother 1999;43:675-81. doi: 10.1093/ $\mathrm{jac} / 43.5 .675$

18. Feng L, Xia Y, Yoshimura T, Wilson CB. Modulation of neutrophil influx in glomerulonephritis in the rat with antimacrophage inflammatory protein-2 (MIP-2) antibody. J Clin Invest 1995;95:1009-17. doi: 10.1172/JCI117745

19. González-Flecha B, Cutrin JC, Boveris A. Time course and mechanism of oxidative stress and tissue damage in rat liver subjected to in vivo ischemia-reperfusion. Clin Invest 1993;91:456-64. doi: 10.1172/JCI116223

20. Miller TJ, Knapton A, Adeyemo O, Noory L, Weaver J, Hanig JP. Cytochrome c: a non-invasive biomarker of druginduced liver injury. J Appl Toxicol 2008;28:815-28. doi: $10.1002 /$ jat. 1347 


\section{In vivo toksičnost novoga antimikotika 2,4-ditiofenoksi-1-jodo-4-bromobenzena: proširenje in vitro istraživanja}

Triazolni antifungalni lijek flukonazol danas je najrašireniji antimikotik u svijetu, mahom zato što dobro prodire $u$ tjelesne tekućine i tkiva. Primijećeno je međutim da ulazi u interakciju s drugim lijekovima, a zbog česte uporabe sve je veći i rizik od stvaranja rezistencije na njega. Stoga se traži njegova dostojna zamjena. Godine 2006. sintetiziran je novi derivat tialobenzena - 2,4-ditiofenoksi-1-jodo-4-bromobenzen $\left(\mathrm{C}_{18} \mathrm{H}_{12} \mathrm{~S}_{2} \mathrm{IBr}\right)$. Iako je ugljikova osnovica tog derivata slična onoj flukonazolu, u prvim in vitro istraživanjima pokazao se puno djelotvorniji. Uslijedilo je in vitro istraživanje njegove citotoksičnosti, u kojem se novi spoj pokazao obećavajućom zamjenom za flukonazol. Cilj je ovog istraživanja bio otići korak dalje i istražiti toksičnost $\mathrm{C}_{18} \mathrm{H}_{12} \mathrm{~S}_{2} \mathrm{IBr}$ in vivo. Odlučili smo se za četverotjedno istraživanje na štakorima Wistar, kojima se je novi antimikotik davao na usta u dozama dva i pol i pet puta nižima od uobičajene doze flukonazola. U životinja nisu primijećene promjene u konzumiranju hrane i vode, ali je relativna težina organa u ženki bila drugačija u odnosu na kontrolnu skupinu, što upućuje na razlike između spolova $u$ metabolizmu lijeka. Za razliku od $\mathrm{C}_{11} \mathrm{H}_{12} \mathrm{~S}_{2} \mathrm{IBr}$, flukonazol je prouzročio značajno povišenje razine leukocita $\mathrm{i}$ smanjenje neutrofila. Ostale hematološke promjene u odnosu na kontrolnu skupinu bile su slične u skupina koje su primale bilo flukonazol bilo novi lijek. Razlike u imunolokalizaciji citokroma c u jetrima i bubrezima pokazatelj su snažnijeg apoptotičkog učinka novoga lijeka, ali se zbog drugih ključnih pokazatelja (biokemijskih i histopatoloških) ne može ništa zaključiti jer oni ne odgovaraju nalazima citokroma c. S obzirom na to da $\mathrm{C}_{18} \mathrm{H}_{12} \mathrm{~S}_{2} \mathrm{IBr}$ snažnije djeluje od flukonazola pri nižim koncentracijama, uz podjednake toksične učinke u štakora, ovaj je novi spoj nesumnjivo obećavajuća alternativa liječenju gljivičnih infekcija. Potrebna su daljnja, podrobnija istraživanja u životinja, koja će obuhvatiti interakcije spojeva i molekularne putove toksičnosti. Bude li se lijek i u tim istraživanjima pokazao boljom alternativom, trebalo bi provesti klinička ispitivanja u ljudi.

KLJUČNE RIJEČI: biokemija; citokrom-c; flukonazol; histopatologija; in vivo toksičnost; krv 